\title{
THE EFFECT OF Sauropus androgynus LEAF EXTRACT ON PERFORMANCE, EGG QUALITY AND CHEMICAL COMPOSITION OF EGGS
}

\author{
U. Santoso and Y. Fenita \\ Faculty of Agriculture, Bengkulu University, \\ Jalan Raya W.R. Supratman, Kandang Limun, Bengkulu 38371A - Indonesia \\ Corresponding E-mail: uripsantoso60@gmail.com
}

Received April 28, 2016; Accepted June 30, 2016

\begin{abstract}
ABSTRAK
Penelitian ini bertujuan untuk menghasilkan telur yang kaya nutrien, tetapi rendah kolesterolnya. Empat puluh delapan ayam petelur strain Dekalb Warren umur 72 minggu dikelompokkan menjadi enam kelompok perlakuan. Satu kelompok, ayam petelur diberi pakan tanpa ekstrak daun katuk (Sauropus androgynus, EDK) sebagai kontrol, dan lima kelompok lainnya diberi pakan yang mengandung masingmasing 9 g EDK, 18 g EDK, 27 g EDK, 36 g EDK, dan 45 g EDK/kg pakan. Rancangan acak lengkap digunakan dalam penelitian ini. Hasil penelitian menunjukkan bahwa suplementasi EDK berpengaruh tidak nyata terhadap produksi telur, konsumsi pakan, konversi pakan, berat telur, berat kuning telur, albumen, berat badan, kulit telur, indeks telur, ketebalan kulit telur, dan indeks kuning telur $(\mathrm{P}>0,05)$, tetapi secara nyata berpengaruh terhadap Haugh Unit, indeks albumen, warna kuning, bau telur, rasa telur, dan warna kuning $(\mathrm{P}<0,05)$. Kadar protein, lemak, kalsium, fosfor, kalium dan besi dalam telur tidak berubah $(\mathrm{P}>0,05)$, namun kadar kolesterol telur secara nyata menurun $(\mathrm{P}<0,05)$. EDK meningkatkan kadar vitamin $\mathrm{A}$ dan $\beta$-karoten $(\mathrm{P}<0,05)$, dan memodifikasi komposisi asam lemak dan asam amino dalam telur. Dapat disimpulkan bahwa suplementasi EDK tidak meningkatkan performa, tetapi memperbaiki kualitas telur dan komposisi kimia telur.
\end{abstract}

Kata kunci: ekstrak daun katuk, kualitas telur, performa, komposisi telur

\begin{abstract}
The purpose of this research was to produce the enriched eggs, but low in cholesterol content. Forty eight layer chickens aged 72 weeks (strain Dekalb Warren) were distributed into six treatment groups. One group of laying hens was fed diets without Sauropus androgynus leaf extract (SALE) as the control, and another five groups were fed diet supplemented to $9 \mathrm{~g}$ SALE, $18 \mathrm{~g}$ SALE, $27 \mathrm{~g}$ SALE, $36 \mathrm{~g}$ SALE, and $45 \mathrm{~g} \mathrm{SALE} / \mathrm{kg}$ diet, respectively. Completely randomized design was used in the present study. The experimental results showed that SALE supplementation had no effect on egg production, feed intake, feed conversion ratio, egg weight, yolk weight, albumen weight, shell egg, egg index, eggshell thickness, and yolk index $(\mathrm{P}>0.05)$, but significantly affected Haugh Unit, albumen index, yolk color, egg odor, egg taste, and yolk color $(\mathrm{P}<0.05)$. The protein, fat, calsium, phosphor, kalium and iron contents of eggs did not change ( $\mathrm{P}>0.05)$, but the cholesterol content of egg was significantly reduced $(\mathrm{P}<0.05)$. In conclusion, the supplementation of SALE did not enhance performance, but it improve egg quality and its chemical composition.
\end{abstract}

Keywords: Sauropus androgynus leaf extract, egg quality, performance, egg composition 


\section{INTRODUCTION}

In the past, researchers emphasized their research to poultry nutrient requirements to support maximum performance. However, recently, they are very interested in enriching or altering the levels of certain nutrients in eggs. This trend is caused by the demands of consumers who want eggs that are rich in nutrients but low in cholesterol (Park et al., 2005; Walker et al., 2012).

Consumer demand for low-cholesterol eggs is very reasonable, because there is a possitve correlation between consuming high-cholesterol eggs and an increase in the risk of atherosclerosis, which can result in up to a coronary heart attack, stroke or other metabolic diseases (Oh et al., 2005). However, it is not easy to lower cholesterol levels without lowering egg production and egg weight (Santoso et al., 2005; Yalcin et al., 2007; Santoso et al., 2010b). In addition, consumers also need eggs, which are enriched in $\beta$-carotene, protein and amino acid, unsaturated fatty acids, especially docosahexaenoic acid (DHA) and eicosapentaenoic acid (EPA), minerals and vitamins (Harris et al., 2007;McCully, 2007; Omenn, 2007). All consumer demands can be met by modifying the nutrients through the addition of a feed additive. However, research on the enrichment of nutrients in eggs as far only focus on one nutrient alone (Park et al., 2005). If the feed additive only provides one type of nutrient enrichment, this requires a lot of feed additive which would be difficult in practice. Thus, it is necessary to find a more effective feed additive, for enriching egg nutrients while lowering cholesterol without lowering production. The potential feed additive for such purposes is Sauropus androgynus leaf extract (SALE) (Santoso, 2001a,b,c), fish oil (Bovet et al., 2007; Cherian, 2008) and vitamin E (Traber and Atkinson, 2007).

Samad et al. (2014) reported that the active compounds in Sauropus androgynus leaf are mainly fatty acid, chlorophyll, alkaloid, glycerol and benzoic acid. Sauropus androgynus leaf is rich in phenolics, flavonoid, and ascorbic acid, which plays an important role as an antioxidant (Supavanich et al., 2012), glutamic acid (Santoso, 2014) and methylpyroglutamate (Agustal et al., 1997), which palys as main compounds in the taste of poultry product, $\beta$-carotene and iron (Santoso et al., 2015). Santoso et al. (2015) reported that the inclusion of Sauropus androgynus leaf powder increased protein, $\beta$ carotene, vitamin A and iron contents of broiler meats.

The present research was conducted to evaluate the effect of Sauropus androgynus leaf extract on performance, egg quality and chemical composition of eggs.

\section{MATERIALS AND METHODS}

\section{Extraction of Sauropus androgynus Leaf}

Sauropus androgynus leaf was dried, and then ground into powder. The powder was then boiled at $60^{\circ} \mathrm{C}$ for 30 minutes in which the ratio Sauropus androgynus leaf with water was 1: 10. After that, the filtrate was filtered. Extraction was done twice. The SALE was then dried at $50^{\circ} \mathrm{C}$ for 36 hours.

\section{Maintenance of Laying Hens}

This study used laying hens aged 72 weeks (strain Dekalb Warren). Completely randomized design was used in the present study. The diet contained $16.5 \%$ crude protein and $2,800 \mathrm{kcal}$ $\mathrm{ME} / \mathrm{kg}$ (NRC, 1994) without antibiotic supplementation.

Our previous results (Santoso et al., 2005) showed that the supplementation of SALE at level of $9 \mathrm{~g} / \mathrm{kg}$ diet was effective to reduce cholesterol content of egg without reducing egg production. It was assumed that extraction of the leaf at $90^{\circ} \mathrm{C}$ would impair active compounds of the leaf, so that it may be benefit if the temperature of extraction was lower than $90^{\circ} \mathrm{C}$. The level of the leaf extract at previous results was used as basic supplementation of the leaf extract. Forty-eight laying hens were grouped into six treatment groups as follows: 1) Laying hens were fed diet without SALE as the control (P0); 2) Laying hens were fed diet with $9 \mathrm{~g}$ SALE $/ \mathrm{kg}$ diet $(\mathrm{P} 1) ; 3)$ Laying hens were fed diet with $18 \mathrm{~g}$ SALE/ $\mathrm{kg}$ diet (P2); 4) Laying hens were fed diet with $27 \mathrm{~g}$ SALE/kg diet (P3); 5) Laying hens were fed diet with $36 \mathrm{~g}$ SALE/kg diet (P4); and 6) Laying hens were fed diet with $45 \mathrm{~g}$ SALE/ $\mathrm{kg} \operatorname{diet}$ (P5).

Eight laying hens for each group were maintained in individual cages. The composition of experimental diet is listed in Table 1. Laying hens were fed for a 30-day trial. They were fed diet for $120 \mathrm{~g} /$ day /bird. Feed intake, feed conversion ratio and egg production were measured weekly. Drinking water was given ad libitum. 
Table 1. The Composition of Experimental Diets

\begin{tabular}{lcccccc}
\hline Feedatuffs $(\mathrm{g} / \mathrm{kg})$ & $0 \mathrm{~g}$ SALE & $9 \mathrm{~g}$ SALE & 18 g SALE & $27 \mathrm{~g}$ SALE & 36 g SALE & 45 g SALE \\
\hline Yellow corn & 510 & 501 & 501 & 492 & 492 & 483 \\
Soybean meal & 140 & 140 & 140 & 140 & 140 & 140 \\
Rice bran & 200 & 200 & 191 & 191 & 182 & 182 \\
Fish meal & 70 & 70 & 70 & 70 & 70 & 70 \\
SALE & 0 & 9 & 18 & 27 & 36 & 45 \\
Oil & 10 & 10 & 10 & 10 & 10 & 10 \\
Calcium carbonate & 35 & 35 & 35 & 35 & 35 & 35 \\
Mineral mixture & 30 & 30 & 30 & 30 & 30 & 30 \\
Premix & 5 & 5 & 5 & 5 & 5 & 5 \\
SALE = Sauropus androgynus Leaf Extract & & & & &
\end{tabular}

\section{Sampling and Laboratory Analysis}

A total of four eggs in each group were collected, and then analyzed the levels of protein, amino acids, $\beta$-carotene, fatty acids, calcium, phosphorus, kalium, iron, cholesterol and vitamin A in egg yolk. Protein content was determined by the method of AOAC (2012). Cholesterol content was determined spectrophotometrically at wavelengths of $490 \mathrm{~nm}$ by the method of Searcy and Berquist (1960) as modified by Bohac et al. (1988), while saponification was done by adding about $3 \%$ of pyrogalol (Živković et al., 2002). Amino acid composition was measured by the method as described by Morel et al. (2003). The lipids were extracted according to Folch et al. (1957) with a chloroform-methanol mixture, and methylized by $20 \%$ boron trifluoride methanol complexin methanol solution (Morrison and Smith, 1964. Fatty acid composition was then determined by gas chromatography. $\beta$-carotene, iron, and vitamin A were measured by the method of Slamet et al. (1990) and Subekti (2003).

To test the quality of the eggs, the eggs were measured weight, eggshell thickness, Haugh Unit, air sac, yolk color and organoleptic tests. To test organoleptic, ten trained sensory panelists were asked to compare the relative palatability of taste and fishy odor. The yolk color test was done by comparing the color of the yolk with yolk color scale. The odor was assessed based on the value of 1 (very fishy), 2 (fishy), 3 (slightly fishy), 4 (less fishy) and 5 (not fishy). Panelists were also asked to taste and rate the taste of bad eggs (value
1) to very good (score 5). The eggs boiled at a temperature of $80^{\circ} \mathrm{C}$ for 20 minutes, cooled and tested the odor and taste.

\section{Data Analysis}

The data of the study were analyzed by Anova and if significantly different then were tested further by Duncan's multiple range test.

\section{RESULTS AND DISCUSSION}

\section{Performance of Laying Hens}

The effect of the SALE on the performance of laying hens is presented in Table 2. The experimental results showed that the SALE did not significantly affect egg production, feed intake and feed conversion $(\mathrm{P}>0.05)$. The results of this study differ from previous research results (Santoso et al., 2005) who reported that egg production was increased by the supplementation of SALE at a level of $9 \mathrm{~g} / \mathrm{kg}$ diet. This difference might be caused by differences in the manufacturing process of SALE where previously extracted at a temperature of $90^{\circ} \mathrm{C}$ while in the present study was extracted at a temperature of $60^{\circ} \mathrm{C}$. Santoso et al. (2010) reported that supplementation of $90 \mathrm{mg}$ non alkaloid extracted from Sauropus androgynus leaf also had no effect on egg production. Hermana et al. (2014) reported that feeding Sauropus androgynus leaf meal at a level of $10 \%$ had no effect on egg production of quails. 
Table 2. The Effect of Sauropus androgynus Leaf Extract on Performance of Laying Hens

\begin{tabular}{lrrrrrr}
\hline \multicolumn{1}{c}{ Variables } & \multicolumn{1}{c}{ P0 } & \multicolumn{1}{c}{ P1 } & \multicolumn{1}{c}{ P2 } & \multicolumn{1}{c}{ P3 } & \multicolumn{1}{c}{ P4 } & \multicolumn{1}{c}{ P5 } \\
\hline Egg production, egg/bird & 21.4 & 22.3 & 22.1 & 23.8 & 20.8 & 22.1 \\
Egg production, g/bird & 1424.5 & 1485.0 & 1477.7 & 1539.6 & 1375.3 & 1454.6 \\
Feed intake, g/bird & 3594.9 & 3596.8 & 3598.4 & 3598.1 & 3599.1 & 3599.6 \\
Feed conversion ratio & 2.57 & 2.45 & 2.44 & 2.35 & 2.65 & 2.49 \\
\hline
\end{tabular}

$\mathrm{P} 0=$ Laying hens were fed diet without Sauropus androgynus leaf extract (SALE) as the control; P1= Laying hens were fed diet supplemented $9 \mathrm{~g}$ SALE/kg diet (P1); P2= Laying hens were fed diet supplemented $18 \mathrm{~g}$ SALE/kg diet; P3= Laying hens were fed diet supplemented $27 \mathrm{~g} \mathrm{SALE} / \mathrm{kg}$ diet; P4= Laying hens were fed diet supplemented $36 \mathrm{~g}$ SALE/kg diet; and P5= Laying hens were fed diet supplemented $45 \mathrm{~g}$ SALE $/ \mathrm{kg}$ diet.

Table 3. The effect of Sauropus androgynus Leaf Extract on Fresh Egg Quality

\begin{tabular}{lcccccc}
\hline \multicolumn{1}{c}{ Variables } & P0 & P1 & P2 & P3 & P4 & P5 \\
\hline Egg weight, g & 66.57 & 67.39 & 66.97 & 64.98 & 66.25 & 65.90 \\
Yolk weight, \% & 23.38 & 24.51 & 25.18 & 24.57 & 25.00 & 23.33 \\
Albumen weight, \% & 63.83 & 62.65 & 62.04 & 63.64 & 62.41 & 64.26 \\
Shell weight, \% & 12.80 & 12.84 & 12.78 & 11.80 & 12.59 & 12.41 \\
Egg index & 0.71 & 0.77 & 0.72 & 0.74 & 0.75 & 0.75 \\
Shell tickness, mm & 0.5 & 0.5 & 0.5 & 0.5 & 0.5 & 0.5 \\
HU & $68.24^{\mathrm{a}}$ & $59.82^{\mathrm{a}}$ & $82.83^{\mathrm{b}}$ & $64.03^{\mathrm{a}}$ & $70.96^{\mathrm{a}}$ & $84.11^{\mathrm{b}^{*}}$ \\
Albumen index & $0.058^{\mathrm{a}}$ & $0.045^{\mathrm{a}}$ & $0.095^{\mathrm{b}}$ & $0.057^{\mathrm{a}}$ & $0.065^{\mathrm{a}}$ & $0.092^{\mathrm{b}^{*}}$ \\
Yolk index & 0.418 & 0.430 & 0.455 & 0.439 & 0.423 & 0.439 \\
Yolk color & $5.62^{\mathrm{a}}$ & $6.93^{\mathrm{b}}$ & $7.56^{\mathrm{b}}$ & $8.0^{\mathrm{bc}}$ & $8.56^{\mathrm{c}}$ & $9.06^{\mathrm{c}^{* *}}$ \\
Air sac, mm & 2.61 & 3.14 & 2.76 & 2.77 & 3.31 & 2.72 \\
\hline
\end{tabular}

Explanation of P0-P5: see Table 2

\section{Egg Quality}

Table 3 shows the effect of Sauropus androgynus leaf extract on fresh egg quality. The results showed that administration of the SALE did not significantly affect egg weight, yolk weight, albumen weight, shell weight, egg index, eggshell thickness, the depth of the air sac, and yolk index $(\mathrm{P}>0.05)$, but significantly affected Haugh Unit (HU), albumen index and yolk color $(\mathrm{P}<0.05) . \mathrm{P} 2$ and $\mathrm{P} 5$ had higher HU and albumen index than the other treatment groups $(\mathrm{P}<0.05)$. P0 had lower yolk color than the other treatment groups. Sauropus androgynus leaf is rich in $\beta$ carotene that may partly cause an increase in yolk color. The results of this study differ from previous research where laying hens were given 9 g SALE $/ \mathrm{kg}$ diet, which showed no increase in yolk color (Santoso et al., 2005) and $\mathrm{HU}$ (Santoso, 2007). This difference is due to the different extraction methods and also due to the level of administration in this study was higher. Hermana et al. (2014), Subekti (2003) and Wiradimadja et al. (2010) reported that feeding Sauropus androgynus leaf meal increased egg yolk color. The yolk color enhancement may be caused by the presence of elevated levels of $\beta$ carotene in eggs (see Table 5). Sauropus androgynus leaf contains $\beta$-carotene at a level of 
3,510.3 $\mu \mathrm{g} / \mathrm{g}$ (Santoso, 2014; Santoso et al., 2015).

Table 4 presents the effect of Sauropus androgynus leaf extract on organoleptic characteristics of eggs. The results showed that administration of SALE significantly reduce the odor, and improve the taste and yolk color ( $\mathrm{P}$ $<0.05)$. The odor of eggs significantly decreased in the presence of SALE. The present study was in agreement with the observation of Santoso (2007) who reported that the supplementation of SALE at level of $9 \mathrm{~g} / \mathrm{kg}$ diet reduced fishy odor of eggs by $22.9 \%$. Compounds that play a role in the decline of the odor is not yet known. Krishnaiah et al. (2007) stated that plants produce an antioxidant compound that includes carotenoids, flavonoids, cinnamic acids, benzoic acids, folic acid, vitamin $\mathrm{C}$, Vitamin $\mathrm{E}$ and tocotrienols, vitamin $A$, palmitic acid, $\beta$-sitosterol, selenium, antraquinone, tannic acid. Katuk leaf was rich in $\beta$ carotene, vitamin $\mathrm{C}$, vitamin $\mathrm{E}$ and flavonoid (Andarwulan et al., 2012), and other phenolic compounds (Nahak and Sahu, 2010), palmitic acid (Santoso, 2014) and chlorophyll (Samad et al., 2014), protein (Madhu et al., 2014). These compounds might contribute inhibiting oxidation of fatty acid of eggs, and therefore reduce the fishy odor of eggs.

An improve in egg taste might relate to glutamic acid content of eggs. Santoso (2014) stated that Sauropus androgynus leaf is rich in glutamic acid, whereas Agustal et al. (1997) reported that Sauropus androgynus leaf is rich in methylpyroglutamate, which may be converted into glutamic acid in the gastrointestinal tract. This study showed that to enhance the taste of eggs, the extract should be supplemented at least at level of $36 \mathrm{~g} / \mathrm{kg}$ diet. Santoso (2007) also

Table 4. The Effect of Sauropus androgynus Leaf Extract on Organoleptic Characteristics of Eggs

\begin{tabular}{lllllll}
\hline \multicolumn{1}{c}{ Variables } & P0 & P1 & P2 & P3 & P4 & P5 \\
\hline Whole egg odor & $2.4^{\mathrm{b}}$ & $2.3^{\mathrm{b}}$ & $2.4^{\mathrm{b}}$ & $1.7^{\mathrm{ab}}$ & $1.30^{\mathrm{a}}$ & $1.45^{\mathrm{a}}$ \\
Egg odor after peeling & $3.6^{\mathrm{b}}$ & $3.4^{\mathrm{b}}$ & $3.2^{\mathrm{b}}$ & $2.45^{\mathrm{a}}$ & $2.30^{\mathrm{a}}$ & $2.00^{\mathrm{a}}$ \\
Egg odor after split & $3.45^{\mathrm{b}}$ & $3.05^{\mathrm{b}}$ & $3.05^{\mathrm{b}}$ & $2.70^{\mathrm{ab}}$ & $2.30^{\mathrm{a}}$ & $2.25^{\mathrm{a}}$ \\
Egg taste & $2.50^{\mathrm{a}}$ & $2.95^{\mathrm{a}}$ & $3.05^{\mathrm{a}}$ & $3.15^{\mathrm{a}}$ & $3.75^{\mathrm{b}}$ & $4.35^{\mathrm{b}^{*}}$ \\
Yolk color & $1.88^{\mathrm{a}}$ & $2.06^{\mathrm{a}}$ & $2.94^{\mathrm{b}}$ & $4.00^{\mathrm{c}}$ & $4.38^{\mathrm{c}}$ & $4.81^{\mathrm{c}^{* *}}$
\end{tabular}

Explanation of P0-P5: see Table 2

Table 5. The Effect of Sauropus androgynus Leaf Extract oComposition of Egg

\begin{tabular}{lllllll}
\hline \multicolumn{1}{c}{ Variables } & \multicolumn{1}{c}{$\mathrm{P} 0$} & \multicolumn{1}{c}{$\mathrm{P} 1$} & \multicolumn{1}{c}{$\mathrm{P} 2$} & \multicolumn{1}{c}{$\mathrm{P} 3$} & \multicolumn{1}{c}{$\mathrm{P} 4$} & \multicolumn{1}{c}{$\mathrm{P} 5$} \\
\hline Protein, \% & 16.60 & 16.52 & 16.63 & 16.69 & 16.76 & 16.69 \\
Fat, \% & 31.90 & 31.85 & 31.89 & 31.85 & 31.86 & 31.86 \\
Calcium, mg/1 & 147.08 & 147.12 & 147.14 & 147.11 & 147.09 & 147.13 \\
Phosphor, mg/1 & 586.04 & 586.10 & 586.04 & 586.07 & 586.10 & 586.06 \\
Iron, mg/1 & 7.25 & 7.23 & 7.27 & 7.25 & 7.28 & 7.28 \\
Kalium, mg/l & 134.32 & 135.30 & 136.21 & 136.62 & 137.24 & 137.55 \\
Cholesterol, mg/100 mg & $3.03^{\mathrm{b}}$ & $2.74^{\mathrm{ab}}$ & $2.55^{\mathrm{a}}$ & $2.53^{\mathrm{a}}$ & $2.41^{\mathrm{a}}$ & $2.31^{\mathrm{a}^{*}}$ \\
Vitamin A $(\mathrm{IU})$ & $1986.9^{\mathrm{a}}$ & $2278.9^{\mathrm{a}}$ & $2271.5^{\mathrm{a}}$ & $2542.1^{\mathrm{b}}$ & $2523.5^{\mathrm{b}}$ & $2754.0^{\mathrm{b}^{* *}}$ \\
$\beta$-carotene $(\mu \mathrm{g} / 100 \mathrm{~g})$ & $632.0^{\mathrm{a}}$ & $662.8^{\mathrm{a}}$ & $761.5^{\mathrm{b}}$ & $800.9^{\mathrm{b}}$ & $816.0^{\mathrm{b}}$ & $893.4^{\mathrm{b}^{*}}$ \\
\hline
\end{tabular}

Explanation of P0-P5: see Table 2 
reported that supplementation of this extract at level of $9 \mathrm{~g} / \mathrm{kg}$ diet did not improve the taste of eggs.

\section{Egg Composition}

Table 5 shows the effect of Sauropus androgynus leaf extract on composition of egg. The results showed that the SALE supplementation did not significantly affect $(\mathrm{P}>0.05)$ the levels of protein and fat in the yolk. This indicates that SALE was unable to lower the fat content of eggs. There are mechanisms in the chicken's body to retain fat content in eggs for normal reproductive function. That is why the levels of fat in eggs are difficult to be lowered. The results of this study are different from when SALE was given in broilers where both levels of these nutrients can be modified (Santoso et al., 2013).

The results showed that the SALE supplementation did not significantly affect levels of calcium, phosphorus, iron, and kalium, but significantly reduced levels of cholesterol $(\mathrm{P}<0.05)$, and increased $(\mathrm{P}<0.05)$ the levels of vitamin $A$ and $\beta$-carotene in egg yolk. The $\mathrm{P} 2, \mathrm{P} 3$, $\mathrm{P} 4$, and $\mathrm{P} 5$ had lower cholesterol contents than the P0 $(\mathrm{P}<0.05)$. The $\mathrm{P} 3, \mathrm{P} 4$, and $\mathrm{P} 5$ had higher vitamin $\mathrm{A}$ than $\mathrm{P} 0, \mathrm{P} 1$ and $\mathrm{P} 2(\mathrm{P}<0.05)$. The $\mathrm{P} 2$, $\mathrm{P} 3, \mathrm{P} 4$, and $\mathrm{P} 5$ had higher $\beta$-carotene than $\mathrm{P} 0$ and $\mathrm{P} 1(\mathrm{P}<0.05)$.

Sauropus androgynus leaf contains compounds that inhibit the metabolism of minerals. In addition, the availability of mineral derived from plants is low. Thus, although Sauropus androgynus leaf is rich in mineral, it was unable to increase the content of the mineral in eggs.

The results of this study were similar to previous research results (Santoso et al., 2005; Subekti et al., 2006) who found that supplementation of SALE can lower cholesterol in egg yolk. Active compounds, which plays as anticholesterol include alkaloid (Santoso et al., 2010b), phytosterol (Subekti, 2007) and flavonoid (Lien et al., 2007).

An Increase in levels of vitamin A and $\beta$ carotene in egg yolk may be caused by $\beta$-carotene in Sauropus androgynus leaf. Subekti (2003) Hermana et al. (2014) and Wiradimadja et al. (2010) reported that feeding Sauropus androgynus leaf meal increased the content of vitamin A of egg yolk. The laboratory analysis in the present study showed that the SALE contains $\beta$-carotene as much as $3,328 \mathrm{mg} / 100 \mathrm{~g}$ extract. Subekti (2003) reported that feeding Sauropus androgynus leaf meal increased the content of $\beta$ carotene of native chicken egg yolk. Santoso et al. (2015) reported that feeding fermented Sauropus androgynus leaf meal increased the content of $\beta$-carotene of broiler meats. $\beta$-carotene is converted to retinal in the intestinal mucosa, then to retinol (vitamin A). The key step for vitamin A formation is the oxidative cleavage of provitamin A carotenoids by $\beta$-carotene15,15dioxygenase (Thurnham, 2007).

Table 6. The Effect of Sauropus androgynus Leaf Extract on Yolk Fatty Acid Composition

\begin{tabular}{lcccccc}
\hline \multicolumn{1}{c}{ Fatty acids, \% } & P0 & P1 & P2 & P3 & P4 & P5 \\
Lauric acid & 0.008 & 0.011 & 0.008 & 0.039 & 0.004 & 0.005 \\
Myristic acid & 0.887 & $0.381^{\mathrm{a}}$ & $0.544^{\mathrm{b}}$ & $0.520^{\mathrm{b}}$ & $0.645^{\mathrm{b}}$ & $0.807^{\mathrm{b}^{*}}$ \\
Palmitic acid & 27.354 & 23.235 & 24.366 & 26.226 & 25.131 & 18.692 \\
Stearic acid & $0.372^{\mathrm{b}}$ & $0.214^{\mathrm{a}}$ & $0.179^{\mathrm{a}}$ & $0.468^{\mathrm{b}}$ & $0.317^{\mathrm{b}}$ & $0.240^{\mathrm{a}}$ \\
Oleic acid & 60.570 & 61.391 & 61.138 & 57.102 & 61.755 & 60.660 \\
Linoleic acid & 6.534 & 8.254 & 8.870 & 7.085 & 7.990 & 6.698 \\
Saturated fatty acid & 28.621 & 23.841 & 25.097 & 27.253 & 26.097 & 19.744 \\
Unsaturated fatty acid & 67.104 & 69.645 & 70.008 & 64.187 & 69.745 & 67.358 \\
Unidentified fatty acid & $4.275^{\mathrm{a}}$ & $6.514^{\mathrm{a}}$ & $4.895^{\mathrm{a}}$ & $8.560^{\mathrm{b}}$ & $4.158^{\mathrm{a}}$ & $12.898^{\mathrm{c}}$ \\
\hline
\end{tabular}

Explanation of P0-P5: see Table 2 


\section{Fatty Acid Composition}

Table 6 shows the effect of Sauropus androgynus leaf extract on yolk fatty acid composition. SALE supplementation significantly reduced stearic acid ( $\mathrm{P}<0.05)$. The supplementation of the extract as much as $9 \mathrm{~g}, 18$ $\mathrm{g}$ or $45 \mathrm{~g} / \mathrm{kg}$ diet reduced the levels of stearic acid when compared with the control. SALE supplementation also significantly reduced myristic acid $(\mathrm{P}<0.05)$, i.e. at the level of extract $9 \mathrm{~g}, 18 \mathrm{~g}$ or $27 \mathrm{~g} / \mathrm{kg}$ diet. Santoso et al. (2015) reported that Sauropus androgynus leaves had myristic acid $8.81 \%$, palmitic acid $48.73 \%$, stearic acid $3.08 \%$, oleic acid $6.72 \%$, linoleic acid $5.11 \%$, which mean that Sauropus androgynus is rich in saturated fatty acid than unsaturated fatty acid. It appears that supplementation of this extract reduced the digestibility and/or absorption of stearic acid and miristic acid. This study differ from the observation of Santoso et al. (2010a) who reported that inclusion of SALE increased miristic acid of broiler meats. Another interesting result is the presence of unidentified compounds. These compounds apparently increased by supplementation of SALE.

\section{Amino Acid Composition}

Table 7 presents the effect of Sauropus androgynus leaf extract on yolk amino acid composition. SALE supplementation significantly affected glutamic acid, arginine and lysine $(\mathrm{P}<0.05)$, but did not affect other amino acid. The $\mathrm{P} 2$ and $\mathrm{P} 3$ had higher glutamic acid than the $\mathrm{P} 0 \quad(\mathrm{P}<0.05)$. The $\mathrm{P} 4$ and $\mathrm{P} 5$ had higher arginine than the $\mathrm{P} 0$ and $\mathrm{P} 1(\mathrm{P}<0.05)$. The $\mathrm{P} 4$ and $\mathrm{P} 5$ had higher lysine than the $\mathrm{P} 0$ and $\mathrm{P} 1$.

Santoso et al. (2015) reported that Sauropus androgynus leaf is rich in glutamic acid, whereas Agustal et al. (1997) reported that Sauropus androgynus leaf is rich in methylpyroglutamate,

Table 7. The Effect of Sauropus androgynus Leaf Extract on Yolk Amino Acid Composition

\begin{tabular}{lcccccc}
\hline \multicolumn{1}{c}{ Amino acids, \% } & P0 & P1 & P2 & P3 & P4 & P5 \\
\hline Aspartic acid & 1.660 & 1.493 & 1.902 & 1.386 & 1.679 & 1.742 \\
Glutamic acid & $2.278^{\mathrm{a}}$ & $2.312^{\mathrm{a}}$ & $2.757^{\mathrm{b}}$ & $2.816^{\mathrm{b}}$ & $2.324^{\mathrm{a}}$ & $2.420^{\mathrm{a}^{*}}$ \\
Serine & 0.891 & 0.880 & 0.949 & 1.041 & 1.103 & 1.026 \\
Glysine & 0.370 & 0.299 & 0.377 & 0.320 & 0.386 & 0.456 \\
Histidine & 0.353 & 0.402 & 0.292 & 0.267 & 0.337 & 0.325 \\
Arginine & $0.574^{\mathrm{a}}$ & $0.646^{\mathrm{a}}$ & $0.748^{\mathrm{ab}}$ & $0.761^{\mathrm{ab}}$ & $0.844^{\mathrm{b}}$ & $1.17 \mathrm{c}^{\mathrm{*}}$ \\
Threonine & 0.505 & 0.455 & 0.544 & 0.553 & 0.589 & 0.494 \\
Alanine & 1.204 & 0.947 & 1.026 & 0.835 & 0.940 & 1.255 \\
Proline & 0.360 & 0.288 & 0.470 & 0.456 & 0.506 & 0.421 \\
Tyrosine & 0.520 & 0.466 & 0.489 & 0.446 & 0.603 & 0.583 \\
Valine & 1.356 & 1.342 & 1.378 & 1.044 & 0.994 & 1.133 \\
Methionine & 0.557 & 0.449 & 0.402 & 0.332 & 0.456 & 0.517 \\
Cystine & 0.345 & 0.451 & 0.280 & 0.333 & 0.437 & 0.330 \\
Isoleucine & 0.689 & 0.773 & 0.606 & 0.609 & 0.934 & 0.733 \\
Leucine & 1.444 & 1.818 & 1.845 & 1.223 & 1.709 & 1.345 \\
Phenylalanine & 0.501 & 0.602 & 0.613 & 0.406 & 0.647 & 0.482 \\
Lycine & $0.686^{\mathrm{a}}$ & $0.757^{\mathrm{a}}$ & $0.839^{\mathrm{ab}}$ & $0.882^{\mathrm{ab}}$ & $0.905^{\mathrm{b}}$ & $1.055^{\mathrm{b}}$ \\
Sulfuric amino acid & 2.346 & 2.718 & 2.527 & 1.888 & 2.602 & 2.192 \\
Total amino acid & 14.293 & 14.380 & 15.517 & 13.990 & 15.393 & 15.495 \\
\hline Explan & & & & & &
\end{tabular}

Explanation of P0-P5: see Table 2 
which may be converted into glutamic acid. An increase in glutamic acid might stimulate arginine synthesis by bacteria, since Hood and Lyman (1950) reported that glutamic acid have an important role in arginine synthesis. In addition, there was also a small contribution of arginine from the extract. The mechanism of an increase in lysine is still unknown. It has been established that lysine is essential amino acid in animal, so that it is not synthesized in the body. Most bacteria synthesize lysine from aspartic acid. SALE increased the number of Bacillus subtilis (Santoso et al., 2001) and Lactobacillus sp (Santoso et al., 2001; Santoso, 2005). It is assumed that these bacteria synthesize lysine from aspartic acid. The SALE supplementation changes the composition of amino acids of the egg yolk, although the egg yolk protein levels unchanged. Santoso et al. (2015) reported that supplementation of Sauropus androgynus leaf meal changed the composition of amino acid of broiler meats.

\section{CONCLUSION}

Sauropus androgynus leaf extract supplementation did not enhance the performance of laying hens, but improved egg quality and organoleptic properties. This extract also increased the contents of vitamin $A$ and $\beta$ carotene, but reduced the content of cholesterol in eggs. However, it was unable to modify the content of protein, minerals and fat in the eggs.

\section{REFERENCES}

Agustal, A., M. Harapini and Chairul. 1997. Analisis kandungan kimia ekstrak daun katuk (Sauropus androgynus (L) Merr dengan GCMS. Warta Tumbuhan Obat Indonesia. 3(3): 31-33.

Andarwulan, N., D. Kurniasih, R. A. Apriady, H. Rahmat, A. V. Roto and B. W. Bolling. 2012. Polyphenols, carotenoids, and ascorbic acid in underutilized medicinal vegetables. J. Fungsional Food. 4: 339-347.

AOAC. 2012. Official methods of analysis. 19ed. Association of Official Analytical Chemist, Washintong, D. C.

Bohac, C. E., K. S. Rhee, H. R. Cross and K. Ono. 1988. Assessment of methodologies for colorimetric cholesterol assay of meats. J. Food. Sci. 53:1642-1644.

Bovet, P., D. Faeh, G. Madeleine, B. Viswanathan and F. Paccaud. 2007. Decrease in blood triglycerides associated with the consumption of eggs of hens fed with foodsupplemented with fish oil. Nutrition. Metabolism \& Cardiovascular Disease.s 17:280-287.

Cherian, G. 2008. Egg quality and yolk polyunsaturated fatty acid statusin relation to broiler breeder hen age and dietary n-3 oils. Poultry Sci. 87:1131-1137.

Folch, J., M. Lees and G. H. Sloane Stanley. 1957. A simple method for isolation and porification of total lipids from animal tissues. J. Biol. Chem. 226:497-509.

Harris, W. S., W. C. Poston and C. K. Haddock. 2007. Tissue $n-3$ and $n-6$ fatty acids and risk for coronary heart disease events. Atherosclerosis. 193:1-10.

Hermana, W., T. Toharmat, Sumiati and W. Manalu. 2014. Performances and egg quality of quail offered feed containing sterol fromkatuk (Sauropus androgynus) and mulberry (Morus alba) leaf meal. Int. J. Poult. Sci. 13:168-172.

Hood, D. W. and C. M. Lyman. 1950. The role of glutamic acid in arginine synthesis by Lactobacillus arabinosus. J. Biol. Chem. 185:39-44.

Krishnaiah, D., R. Sarbatly and A. Bono. 2007. Phytochemical antioxidants for health and medicine - A move towards nature. Biotechnol. Molecular Biol. Rev. 1: 97-104.

Lien, T. F., H. S. Yeh and W. T. Su. 2007. Effect of adding extracted hesperetin, naringenin and pectin on egg cholesterol, serum traits and antioxidant activity in laying hens. Arch. Anim. Nutr. 62: 33-43.

Madhu, C.S., H.M.G. Manukumar and P. Basavaraju. 2014. New-vista in finding antioxidant and anti-inflammatory property of crude protein extract from Sauropus androgynus leaf. Acta Sci. Pol. Technol. Aliment. 13:375-383.

McCully, K. S. 2007. Homocysteine, vitamins, and vascular disease prevention. Am. J. Clin. Nutr. 86(suppl):1563S-8S.

Morel, P. C. H., J. Melai, S. L. Eady and G. D. Coles, 2003. Effect of non-starch polysaccharides and resistant starch on mucin secretion and endogenous amino acid losses in pigs. Asian-Aust. J. Anim. Sci. 18:1634-1641.

Morrison, W. R. and M. L. Smith. 1964. Preparation of fatty acid methyl esters and 
dimethylacetates from lipid with boron trifluoride methanol. J. Lipid Res. 5:600608.

Nahak, G. and R. K. Sahu. 2010. Free radical scavenging activity of multi-vitamin plant (Sauropus androgynus L. Merr). Researcher. 2: 6-14.

National Research Council (NRC). 1994. Nutrient Requirement of Poultry. Ninth Revised Edition. National Academiy Press. Washington, D. C.

Oh, K., F. B. Hu, J. E. Manson, M. J. Stampfer and W. C. Willett. 2005. Dietary fat intake and risk of coronary heart disease in women: 20 years of follow-up of the nurses' health study. Am. J. Epidemiol. 161:672-679.

Omenn, G. S. 2007. Chemoprevention of lung cancers: lessons from CARET,the betacarotene and retinol efficacy trial, and prospectsfor the future. Eur. J. Cancer Prevention. 16:184-191.

Park, S. W., H. Namkung, H. J. Ahn and I. K. Paik. 2005. Enrichment of vitamins D3, K and iron in egg of laying hens. Asian-Aust. J. Anim. Sci. 18:226-229.

Samad, A.P.A., U. Santoso, M.C. Lee and F.H. Nan. 2014. Effects of dietary katuk (Sauropus androgynus L. Merr.) on growth, non-specific immune and diseases resistance against Vibrio alginolyticus infection in grouper Epinephelus coioides. Fish Shellfish Immunol. 30: 582-589.

Santoso, U. 2001a. Effect of Sauropus androgynus Extract on the carcass quality of broiler chicks. Buletin Ilmu Peternakan dan Perikanan 7:22-28.

Santoso, U. 2001b. Effect of Sauropus androgynus extract on the performance of broiler. Buletin Ilmu Peternakan dan Perikanan. 7:15-21.

Santoso, U. 2001c. Effect of Sauropus androgynus extract on organ weight, toxicity and number of Salmonella $s p$ and Escherichia coli of broilers meat. Buletin Ilmu Peternakan dan Perikanan. 7:162-169.

Santoso, U., E. Hadayani and Suharyanto. 2001. Effect of Sauropus androgynus (katuk) leaf extract on growth, fat accumulation, and fecal microorganisms in broiler chickens. Jurnal Ilmu Ternak dan Veteriner. 6: 220226.

Santoso, U. 2005. Pengaruh pemberian ekstrak daun katuk dalam ransum terhadap produksi, kadar nitrogen dan fosfor, dan jumlah koloni mikrobia pada feses ayam petelur. J. Indon. Trop. Anim. Agric., 30(4): 237-241.

Santoso, U., J. Setianto and T. Suteky. 2005. Effect of Sauropus androgynus (katuk) extract on egg production and lipid metabolism in layers. Asian-Aust. J. Anim. Sci. 18:364-369.

Santoso, U. 2007. Pengaruh penambahan ekstrak daun katuk terhadap kualitas telur dan berat organ dalam. Jurnal Sain Peternakan Indonesia, 2: 5-10.

Santoso, U., Kususiyah and Y. Fenita. 2010a. The effect of Sauropus androgynus extract and lemuru oil on fat deposition and fatty acid composition of meat in broiler chickens. J. Indonesian Trop. Anim. Agric., 35:48-54.

Santoso, U., T. Suteky and Y. Fenita. 2010b. Effects of supplementation of alkaloid and non alkaloid from Sauropus androgynus leaves on egg production and lipid profil in layer chicken. J. Anim. Prod. 12:184-189.

Santoso, U., Kususiyah and Y. Fenita. 2013. Effect of Sauropus androgynus leaves extract in fat deposition in broilers fed low containing diets. J. Indonesian Trop. Anim. Agric., 38:176-184.

Santoso, U. 2014. Katuk, Tumbuhan Multi Khasiat. BPFP, Unib, Bengkulu.

Santoso, U., Y. Fenita, Kususiyah and I. G. N. G. Bidura. 2015. Effect of fermented Sauropus androgynus leaves on meat composition, amino acid and fatty acid compositions in broiler chickens. Pak. J. Nutr. 14:799-807.

Slamet, D. S., M. K. Mahmud, Muhilal, D. Fardiaz, and Simarmata, 1990. Handbook of Nutritional Analysis. Departemen Kesehatan RI, Dirjen Bina Gizi Masyarakat, Jakarta.

Subekti, S. 2003. Kualitas Telur and Karkas Ayam Lokal yang Diberi Tepung Daun Katuk dalam Ransum. Master Thesis, IPB. Bogor.

Subekti, S. 2007. Komponen Sterol dalam Ekstrak Daun Katuk (Sauropus androgynus) dan Hubungannya dengan Sistem Reproduksi Puyuh. Ph.D Thesis, IPB, Bogor.

Subekti, S., W. G. Piliang, W. Manalu and T. B. Murdiati. 2006. Penggunaan tepung daun katuk dan ekstrak daun katuk (Sauropus androgynus L.Merr) sebagai substitusi ransum yang dapat menghasilkanproduk Puyuh Jepang rendah kolesterol. Jurnal Ilmu Ternak dan Veteriner. 14:254-259. 
Supapvanich, S., R. Arkajak and K. Yalai. 2012. Maintenance of postharvest quality and bioactive compounds of fresh-cut sweet leaf bush (Sauropus androgynus L. Merr.) through hot $\mathrm{CaCl} 2$ dips. Int. J. Food Sci. Technol. 47: 2662-2670.

Traber, M. G. and J. Atkinson. 2007. Vitamin E, antioxidant and nothing more. Free Radical Biol. Medi. 43:4-15.

Thurnham, D. I. 2007. Review Bioequivalence of $\beta$-carotene and retinol. J. Sci. Food Agric. 87:13-39.

Walker, L. A., T. Wang, H. Xin and D. Dolde. 2012. Supplementation of laying-hen feed with palm tocos and algae astaxanthin for egg yolk nutrient enrichment. J. Agric.
Food Chem. 60:1989-1999.

Wiradimadja, R., H. Burhanuddin and D. Saefulhadjar. 2010. Peningkatan kadar vitamin A pada telur ayam melalui penggunaan daun katuk (Sauropus androgynus L. Merr) dalam ransum. Jurnal Ilmu Ternak 10:90-94.

Yalcin, S., I. Obasilar, A. Sehu and S. Yalcin. 2007. The Effects of dietary garlic powder on the performance, egg traits and blood serum cholesterol of laying quails. AsianAust. J. Anim. Sci. 20:944-947.

Živković, D., V. Perić, M. Barać and M. Perunović, 2002. Cholesterol content in meat of some Cyprinidae. J. Agric. Sci. 47:179-187. 